\title{
6 Towards Protection of Vulnerable Labour Migrants in Sweden
}

\author{
The Case of the Thai Berry Pickers
}

Petra Herzfeld Olsson

\begin{abstract}
This chapter illustrates how the scandals that followed the 2008 reform prompted the authorities and the trade union movement to adopt a - fairly successful - coordinated approach to prevent further exploitation of a particularly vulnerable group of migrant workers - seasonal migrant berry pickers from third countries. The result illustrates that, because labour migration gives rise to specific challenges in efforts to enforce domestic labour standards, the stakeholders responsible for the enforcement of these rights must resort to alternative methods, not used for domestic workers. Olsson also shows that well-targeted immigration control measures, in combination with other activities, can play an important role in strengthening the position of migrant workers.
\end{abstract}

Keywords: seasonal workers, trade unions, targeted immigration control measures, berry pickers

Seasonal work is not considered to be particularly attractive for domestic workers in Western economies. ${ }^{1}$ Nevertheless, production in need of seasonal

1 International Labour Organization (2010), International Labour Migration. A rights-based approach', Geneva p. 85; COM (2010), 379, Proposal for a DIRECTIVE OF THE EUROPEAN PARLIAMENT AND OF THE COUNCIL on the conditions of entry and residence of third-country nationals for the purposes of seasonal employment, pp. 2-3.

Rijken, Conny and Tesseltje de Lange (eds): Towards a Decent Labour Market for Low Waged Migrant Workers. Amsterdam: Amsterdam University Press, 2018 DOI: 10.5117/9789462987555_OLSS 
work continues to take place. ${ }^{2}$ Often, this is made possible through an influx of workers through seasonal labour migration schemes. ${ }^{3}$ A seasonal migrant worker is commonly understood as 'a migrant worker whose work by its character is dependent on seasonal conditions, and is performed only during part of the year'. ${ }^{4}$ In Sweden, one quarter of all third-country national ${ }^{5}$ labour migrants, admitted to the Swedish labour market, are seasonal workers who come to pick berries. ${ }^{6}$ Their work is similar in many respects to the agricultural work carried out by seasonal migrant workers around Europe ${ }^{7}$ - it is short-term, physically challenging, and sometimes dangerous and isolated -, but their environment is a bit different. ${ }^{8}$ Instead of working at farms and greenhouses, they pick wild berries that grow in the remote forests in the northern parts of Sweden.

The Swedish labour migration regime was reformed in 2008. The new system is described as the most open labour migration regime within the OECD. ${ }^{9}$ Through this reform, any employer, irrespective of branch, can recruit workers from third countries. The reform turned people's attention to the berry-picking industry and opened the door for new, sometimes unscrupulous players. ${ }^{10} \mathrm{~A}$ number of scandals came to light, instances in which berry pickers were left with no remuneration and huge debts. ${ }^{11}$ There were even suggestions that some of these workers might be victims of trafficking and so-called 'modern slavery'. ${ }^{12}$

$2 \operatorname{COM}(2010), \mathrm{n} 1, \mathrm{pp} .2-3$.

3 ILO, n 1, pp. 29, 85 .

4 ILO, n 1, p. 29.

5 'Third-country national' in this context means non-Nordic, non-EEA, or non- Swiss citizens.

6 Statistics published by the Swedish Migration Agency for the years 2016 and 2017. Available at: https://www.migrationsverket.se/Om-Migrationsverket/Statistik/Arbetstagare---de-storstayrkesgrupperna.html.

7 ILO, n 1, p. 85; J. Hunt (2014), 'Making the CAP Fit: Responding to the Exploitation of Migrant Agricultural Workers in the EU' The International Journal of Comparative Labour law and Industrial Relations, 30(2) pp. 132, 135; See also the judgment from the European Court of Human Rights, Affaire Chowdury et Autres c. Grèce (requiete 21884/15) 30 March 2017 para. 139, in which a number of strawberry pickers in Greece were victims of forced labour.

8 C. Woolfson, P. Herzfeld Olsson, and C. Thörnqvist (2012), 'Forced Labour and Migrant Berry Pickers in Sweden' The International Journal of Comparative Labour Law and Industrial Relations, 28(2) pp. 147, 152 .

9 OECD (2011) Recruiting Immigrant Workers: Sweden 2011, OECD, p. 32.

10 C. Woolfson et al., n. 8, p. $15^{2}$.

11 Ibid p. 153; LO (2013) Fusk och utnyttjande - om avregleringen av arbetskraftsinvandringen, Landsorganisationen i Sverige.

12 L. Vogazides and C. Hedberg (2014), 'Människohandel för tvångsarbete och exploatering av arbetskraft i Sverige: Exempel från restaurang och bärbranscherna', ADSTRINGO, pp. 69-70. 
In some jurisdictions, the approach adopted to handling the exploitation of seasonal migrant workers in the agricultural sector has been to shift priorities 'from securing decent working conditions for agricultural workers, given their especial vulnerability, to combatting irregular migration, forced labour, and human trafficking. ${ }^{13}$ The dangers involved in shifting from an 'employment' agenda to an 'immigration control' agenda, in an effort to protect particularly vulnerable labour migrant groups, has been highlighted, because, ultimately, it may turn out to be damaging to the interests of the majority of workers in this category. ${ }^{14}$

In this chapter, I will illustrate how the scandals that followed the 2008 reform prompted the authorities and the trade union movement to adopt a - fairly successful - coordinated approach to prevent further exploitation of this particularly vulnerable group of migrant workers - seasonal migrant berry pickers from third countries. The result illustrates - as has been described elsewhere - that, because labour migration gives rise to specific challenges in efforts to enforce domestic labour standards, the stakeholders responsible for the enforcement of these rights must resort to alternative methods, not used for domestic workers. The chapter also shows that well-targeted immigration control measures, in combination with other activities, can play an important role in strengthening the position of migrant workers.

The chapter is organised as follows. In section two, the Swedish labour migration regime is presented. In section three, the coordinated measures taken to prevent further exploitation of the berry pickers are discussed; first, measures categorised as immigration control will be dealt with, followed by the innovative trade union strategies adopted. In section four, the role of other stakeholders in promoting decent conditions for the berry pickers is touched upon. In section five, some remaining challenges are discussed, and, finally, in section six, the chapter ends with some conclusions.

13 A.C.L. Davies (2014), 'Migrant Workers in Agriculture - A Legal Perspective', in C. Costello and M. Freedland (eds.), Migrants at Work, Oxford University Press, p. 79.

14 A.C.L. Davies, n. 13, p. 79; B. Anderson (2010), 'Migration, Immigration Controls and the Fashioning of Precarious Workers, Work, employment and society, 24(2) p. 301; J. Fudge (2012), 'Precarious Migrant Status and Precarious Employment - The Paradox of International Rights for Migrant Workers,' Comparative Labour Law \& Policy Journal, 34 p. 96. 


\section{The Rules on Immigration for Seasonal Work: The 2008 Reform $^{15}$}

Before the 2008 reform, the entry into Sweden of all groups of labour migrants depended mainly on the outcome of labour market tests carried out by the labour market authorities, together with the trade unions. ${ }^{16}$ A permit was available specifically for seasonal work. ${ }^{17}$ The wild berry-picking industry, to some extent, operated outside that regime. Berry pickers could stay up to three months on tourist visas and pick wild berries without a work permit. ${ }^{18}$ One intention behind the 2008 reform was to establish a labour migration system that would apply in the same manner to all labour migrant groups, including seasonal berry pickers. Thus, the specific work permit for seasonal work was eliminated. ${ }^{19}$

To enter Sweden, a third-country national needs a Schengen visa or a national visa. ${ }^{20}$ Stays longer than 90 days, as a main rule, require a residence permit. ${ }^{21}$ All third-country nationals who work in Sweden must have a work permit. This applies both if the third-country national is employed in Sweden or continues to be employed by a foreign employer and is posted to Sweden. ${ }^{22}$

This labour migration scheme is purely driven by employer demand. No labour market tests are conducted, no skill preferences based in law or quotas apply, and the system is open to all sectors of the labour market. ${ }^{23}$

15 This section of the text is based on a similar section by this author in (2017) 'The shortcomings of equal treatment for labour migrants' in K. Ahlberg and N. Bruun (eds.), The New Foundations of Labour Law, Peter Lang, Frankfurt am Main.

16 OECD, n. 9, p. 57 .

17 Ibid p. 58 .

18 C. Calleman and P. Herzfeld Olsson (2015), 'Inledning' in C. Calleman and P. Herzfeld Olsson (eds.), Arbetskraft från hela världen - hur blev det med 2008 års reform? DELMI, 9 pp. 13-14.

19 Legislative Bill 2007/08:147, p. 34.

20 Aliens Act 2005:716 ch $2 \mathrm{sec} 3$. A number of exceptions apply, for example, for citizens in EEA countries, Aliens Act 2005:716 ch $2 \mathrm{sec} 8 \mathrm{a}$. Citizens from the countries mentioned in this list need a visa to enter Sweden. Available at: http://www.government.se/government-policy/ migration/list-of-foreign-citizens-who-require-visa-for-entry-into-sweden.

21 Aliens Act 2005:716, ch. 2 sec. 5. Exceptions apply, for example, to citizens in Denmark, Norway, Iceland, and Finland, citizens of EEA countries, and for those with a visa for longer than three months, Aliens Act (2005:716) ch. 2 sec. 8 b.

22 Aliens Act 2005:716 ch. 2 sec 7. Exceptions apply for citizens in Denmark, Finland, Iceland, and Norway, as well as EES citizens, Ch. 2 sec. $8 \mathrm{c}$ Aliens Act and for specific categories, Aliens Ordinance 2006:97 ch. 5 secs. 1 and 2.

23 However, the employers must respect the principle of European Union preference. In reality, that only means that the vacancy must have been published on the websites of the Swedish 
Individual employers decide whether they need to recruit workers from third countries, but it is the migrant worker who applies for the work permit. For a successful application, the migrant worker needs to receive an offer of employment. To ensure that migrant workers do not replace domestic workers, the terms of employment offered must be similar to those enjoyed by domestic workers. ${ }^{24}$ The law therefore prescribes that the worker must be offered a wage, insurance, and other terms of employment that are not worse than those laid down in the relevant collective agreements, or provided for by custom in the occupation or industry. ${ }^{25}$

The Migration Agency makes decisions on work and residence permits. The Agency has designed a form - the Offer of employment - that must be filled in and accompany the application for a work permit. ${ }^{26}$ In the Offer of employment form, the parties must declare whether the employer is bound by a collective agreement, and, in that case, identify the trade union party. It must also specify the wage, working time, applicable insurances, kind of employment (indefinite or temporary), and the period of employment. The combined effect of wage and working time is also important to fulfil the last legal requirement for being granted a work permit. Migrant workers must be able to support themselves, meaning that their total income must be higher than the level for social assistance for maintenance (around 1300 euros per month). ${ }^{27}$

Trade unions are given a specific role in the application procedure. The relevant trade union shall be given an opportunity to verify whether the terms laid down in the offer of employment are in accordance with the collective agreements or custom..$^{28}$ The trade unions are given this task as they are familiar with the content of the collective agreements. ${ }^{29}$ However, they are not obliged to give their opinion, and the Migration Agency is not bound to follow the opinion given. Some trade unions refrain from giving

Public Employment Service and the European Employment Services for at least ten days. If that is done, the employer is free to offer the job to anyone, Legislative Bill 2007/08:147 p. 36 and Legislative Bill 2013/14:227 p. 8. This requirement does not apply to posted workers, however.

24 Legislative Bill 2007/08:147, p. 27.

25 Aliens Act 2005:716, ch. 6 sec. 2.

26 Available at: https://www.migrationsverket.se/download/18.5e 83388 f141c129ba6312e ab/1485556063715/anst_erbj_232011_sv.pdf.

27 Aliens Act 2005:716 ch. 6 sec. 2; MIGR 2015:11 (Case law from the Migration Court).

28 Aliens Ordinance 2006:97, ch. 5 sec. 7 a. Available at: http://www.migrationsverket.se/dow nload/18.5e83388f141c129ba6312b76/1485556063117/233011+Fackligt+yttrande.pdf 29 Legislative Bill 2013/14:227 p. 20. 
opinions if the employer is not bound by a collective agreement. ${ }^{30}$ The argument in such cases is that the trade unions do not have the means to control whether the offered conditions are in fact applied if there is no collective agreement..$^{31}$ In those cases, the Migration Agency must independently verify whether the offered terms are sufficient.

All work permits are temporary. They are granted for the duration of the employment offered, but for a maximum of two years. Work permits may be extended an unlimited number of times, however, the total period may only exceed four years, in exceptional cases. ${ }^{32}$ For each extension a new offer of employment is required from an employer. After having worked legally in Sweden for a total of four years within a seven-year period, the migrant worker may be granted a permanent residence permit. ${ }^{33}$ In 2016, 1784 foreigners were granted a permanent residence on that ground. ${ }^{34}$

The work permit is tied to a specific employer and to a specific type of work (occupation) for the first two years, but thereafter it is tied only to a specific type of work..$^{35}$ If migrant workers want to change employer or type of work, they must apply for a new work permit. That can be done from within Sweden as long as the previous residence permit is still valid.

The work permit and/or residence permit may be revoked if the employment has ceased, and until December 2017 should be revoked if the working conditions applied did not fulfil the requirements of the law; this might mean, for example, that the wage is lower than the wage provided for in the relevant collective agreement. This latter rule was criticised as being rigid, leading to unjust results. Hence, in December 2017 a change entered into force making it possible for the employer to correct mistakes a posteriori and avoid a revocation of the work permit. ${ }^{36}$ In case the employment has still not begun four months after arrival of the migrant worker, the permit will be revoked. To ensure that migrant workers are not too dependent on the employers, they can stay in Sweden for three or four months to search for a new job if they lose the job to which the work permit is connected. ${ }^{37}$

$3^{0}$ See, for example, statements by the biggest white-collar trade union UNIONEN. Available at: https://www.unionen.se/rad-och-stod/yttrande-arbetstillstand.

31 The blue-collar trade union for hotel and restaurant workers. Available at: https://www. svd.se/hrf-kraver-kollektivavtal-for-att-ge-arbetstillstand

32 Aliens Act 2005:716, ch. 6 sec. 2 a.

33 Aliens Act 2005:716, ch. 5 sec. 5 .

34 E-mail from the statistical department at the Migration Agency (26 September 2017).

35 Aliens Act 2005:716, ch. 6 sec. 2 a.

36 Aliens Act 2005:716, ch. 7 secs. 3 and 7e. Legislative Bill 2016/17:2012.

37 Aliens Act 2005:716 ch. 7 secs. 3 and 7 e. 
These rules apply in their entirety to the seasonal berry pickers who are the focus of this chapter, as well as to all other labour migrant groups. Normally, the Thai berry pickers only stay two or three months in Sweden, which means that some provisions are less relevant to them. For example, the short stays make it very difficult for the berry pickers to ever fulfil the conditions for a permanent residence permit.

\section{A Coordinated Effort to Prevent Abuse in the Berry- picking Sector}

\subsection{Introduction}

After the 2008 labour migration reform was put into force, reports came to light of grave misconduct and abuse of berry pickers. ${ }^{8}$ Since 2014, the situation has improved. The change is connected to a fairly coordinated effort to prevent further abuse. Before explaining the measures taken, however, we shall provide a short introduction to the berry-picking industry in order to clarify the mechanisms involved.

\subsection{The Berry-picking Sector}

In Sweden, the Right of Public Access applies. ${ }^{39}$ This means that everyone has a right to access the countryside and freely pick the available wild growing berries, such as blueberries, lingonberries, and cloudberries. ${ }^{40}$ Swedish people have always picked berries for their household needs, and, to a certain extent, for commercial purposes.$^{41}$ During the past four decades, however, the berry-picking scene has changed character and it has developed into an international industry. ${ }^{42}$ Blueberries are rich in antioxidants and are now

38 Woolfson et al., n. 8, p. 148; K. Krifors (2017), 'Managing Migrant Workers - moral economies of temporary labour in the Swedish IT and wild berry industries,' Linköping Studies in Arts and Sciences No. 717 Linköping, p. 79 .

39 The instrument of government 1974:152, ch. 2 sec. 15.

40 Swedish Environment Protection Agency. Available at: http://www.swedishepa.se/Enjoyingnature/The-Right-of-Public-Access/This-is-allowed/Picking-flowers-berries-mushrooms-etc/. 41 L. Jonsson and R. Uddstål (2002), En beskrivning av den svenska skogsbärsbranschen, Sveriges Lantbruksuniversitet, p. 12.

42 On this theme, see: C. Hedberg (2015), 'Thailändska bärplockare - hushållsstrategier på en global arbetsmarknad', in C Calleman and P. Herzfeld Olsson (eds.), Arbetskraft från hela världen, DELMI, p. 119; Krifors, n. 38 . 
used in the pharmaceutical and beauty industries in Asia. ${ }^{43}$ Additionally, most of the berries are currently picked by seasonal labour migrants from Thailand. ${ }^{44}$

The Thai berry pickers, for tax-related reasons, are employed by temporary work agencies in Thailand. ${ }^{45}$ The berry pickers employed by these agencies are exempted from paying taxes in Sweden ${ }^{46}$ nevertheless, the Swedish berry companies play a crucial role in this system. ${ }^{47}$ 'They order' a specific number of berry pickers from the Thai temporary work agencies; a contract is drawn up between the temporary work agency and the Swedish berry picking company, ${ }^{48}$ and the Thai berry pickers deliver the berries picked to the Swedish berry company. ${ }^{49} \mathrm{It}$ is also this Swedish berry-picking company that offers the employment in Sweden in the work permit application process, and that takes care of all the practical arrangements in Sweden, such as transport and accommodation. ${ }^{50}$ The Swedish berry-picking companies sell the berries to merchants, wholesalers, or retailers who take the berries to the world market. ${ }^{1}$

\subsection{Increased Immigration Control}

After the problematic berry-picking season of 2009, the government and the Migration Agency realised that additional measures had to be taken to prevent further abuse of this group of migrant workers. It turned out that the new rules had not been properly implemented in relation to the berry pickers. This is partly explained by the lack of a useful comparator regarding the offered wage, something to which we shall return in the next section. Hence, the Migration Agency took responsibility for the application

43 Hedberg, n. 42, p. 119; M. Wingborg (2016), 'En alltmer osäker bransch - om villkoren för utländska bärplockare 2016, Arena Idé, p. 26.

44 M. Wingborg (2016), n. 43, p. 11.

45 Ibid.

46 Act (1991:586) on particular income tax, sec. 6 1a, b; See also Hedberg, n. 43, p. 124; M. Wingborg (2016), n. 43, p. 18.

47 Hedberg, n. 42, pp. 126-127.

48 M. Wingborg (2015), 'Så var säsongen för utländska bärplockare 2015', Arena idé, p. 8.

49 Hedberg, n. 42, p. 123; M. Wingborg (2016), n. 43, p. 16.

50 Migration Agency Website. Available at: https://www.migrationsverket.se/English/Otheroperators-English/Employers/Special-rules-for-certain-occupations-and-citizens-of-certaincountries/Berry-pickers/When-you-are-employing-or-engaging-berry-pickers.html.

$5^{1}$ Hedberg, n. 42, p. 123. 
process from the embassies in the countries concerned..$^{2}$ However, new scandals took place in 2010, involving unreliable employers and insufficiently informed berry pickers. The latter often did not know what kind of work they would do and were not ready for the hard work expected from them. In 2011, the Swedish Migration Agency therefore introduced targeted controls of the berry pickers' employers or of the Swedish berry companies hiring the berry pickers. Thus, since 2011, before an application for a work permit can be approved, the entity offering the labour migrant employment has to provide the Migration Agency with additional guarantees, such as:

- A guarantee that wages will be paid despite poor availability of berries, or to berry pickers not skilled enough to pick the required amounts. The Migration Agency normally requires a bank guarantee.

- Proof that the berry pickers have been informed about the kind of work they are supposed to do, the working conditions, the Right of Public Access, and Swedish road safety rules (they have to drive to the different spots where the berries grow).

- Foreign temporary work agencies must have a representative present in Sweden and register a branch there. ${ }^{53}$

The new controls had some effect, and the 2012 season was fairly calm. However, in 2013, new problems occurred. A number of berry pickers were denied any wages at all and left with debts. ${ }^{54}$ Subsequently, employer monitoring was carried out even more thoroughly and, during the 2014 season, four out of sixteen Swedish berry-picking companies were denied the right to bring berry pickers into Sweden through foreign temporary work agencies. ${ }^{55}$ Now, the employers/companies hiring berry pickers must show that they are able to organise transport, room, board, and other practical matters in a manner that is customary for the industry. Additionally, all costs that the person employed or hired is liable for, must also be made clear..$^{6}$

52 M. Wingborg (2011), 'Mors lilla Olle - så exploateras asiatiska bärplockare i de svenska skogarna', Swedwatch rapport 41, p. 26. Available at: http://www.jureka.net/jureka/read. asp?NewsId $=8548$

53 M. Wingborg (2011), 'Mors lilla Olle - så exploateras asiatiska bärplockare i de svenska skogarna', Swedwatch rapport 41, p. 27. Available at: http://www.jureka.net/jureka/read. asp? NewsId $=8548)$.

54 M. Wingborg (2014), 'Villkoren för utländska bärplockare säsongen 2014', Arena Idé, pp. 12 and 14.

55 Ibid p. 10.

56 Available at:https://www.migrationsverket.se/English/Other-operators-English/Employers/ Special-rules-for-certain-occupations-and-citizens-of-certain-countries/Berry-pickers.html. 
The increased checks on employers and companies hiring migrant workers, before work permits are approved, seems to have been effective. During recent seasons, no scandals have been reported. This indicates that immigration control measures targeting the reliability of employers before arrival can be an important component of a sustainable labour migration system. However, these measures would have been rather pointless, if not accompanied by trade union efforts. These efforts will be the focus of the next section. First, a short overview of the Swedish labour law model is needed to understand the context in which the trade unions operate.

\subsection{Innovative Trade Union Strategies}

\subsubsection{The Role of Trade Unions and Collective Agreements in the Swedish} Labour Market

Collective agreements are the most important sources of norms regulating wages and employment conditions in Swedish law. In 2014, 85 per cent of the labour force in the private sector was covered by collective agreements and 64 per cent were members of a trade union. ${ }^{57}$ This is explained by the high level of employer organisation. Organised employers employed 89 per cent of the labour force in $2014 \cdot{ }^{5}$ An employer who is a member of an employment organisation is automatically bound by the collective agreements that this organisation has concluded. The terms of the collective agreement have to be applied to all relevant workers employed by the employer, regardless of their trade union membership. However, there is no mechanism for extending the binding force of collective agreements to others in a sector, different than the signatory parties and their members, and thus to give the collective agreement erga omnes effect. ${ }^{59}$ At the same time, working hours, employment protection and occupational health and safety is also protected by statutory regulation. A crucial feature of the Swedish system, however, is the absence of legislative provisions on minimum wages - a fact that promotes the conclusion of collective agreements.

57 Medlingsinstitutet (2017), Avtalsrörelsen och lönebildningen 2016, Medlingsinstitutets årsbok, Medlingsinstitutet, pp. 216 and 222.

58 Ibid.

59 K. Ahlberg and N. Bruun (2005), 'Sweden: Transition through Collective Bargaining' in T. Blanke, R. Blainpain, and E. Rose (eds.), Collective Bargaining and Wages in Comparative Perspective: Germany, France, the Netherlands, Sweden and the United Kingdom, Kluwer Law International, p. 122. 
Collective autonomy and nonintervention by the state are essential features of the regulation of wages and working conditions in the Swedish labour market. ${ }^{60}$ This is also true when it comes to the responsibility for monitoring that the employment conditions laid down in law and collective agreements are applied. This responsibility, with the exception of the monitoring function of the Work Environment Authority, is borne alone by the parties to the collective agreement, the trade union, and the employer organisation or employer. The local trade union's representatives play a crucial role in this process. They often carry out monitoring and take the main responsibility for ensuring that the rights and obligations in a collective agreement are upheld at the work site. If the conditions are not met, the trade union can demand damages in the Labour Court. ${ }^{61}$ The Work Environment Authority monitors the application of occupational health and safety provisions, and, if not dealt with in a collective agreement, working time provisions.

\subsubsection{Appointing a Responsible Trade Union}

In the Swedish system, it is obviously difficult to uphold decent working standards in a sector without the involvement of a trade union. This partly explains the failed enforcement of the 2008 reform in relation to the seasonal berry pickers in the 2009 season. At that point, no trade union had taken on the responsibility to organise berry pickers, or conclude collective agreements applicable to them. The government claimed that bad employment conditions for berry pickers had to be solved mainly by the mechanisms available within the Swedish labour law model. ${ }^{62}$ Thus, the trade union movement had to act. In 2009, the Swedish blue-collar trade union confederation LO decided that the Swedish Municipal Workers Trade Union (Kommunal) should be allocated responsibility for the berry pickers. ${ }^{6}$ They had previously organised seasonal workers working in the agricultural and forest sectors.

\subsubsection{Towards a Suitable Collective Agreement}

When a responsible trade union was appointed, it was easy to decide which collective agreement should be applied. The collective agreement that

60 Ibid.

61 T. Sigeman and E. Sjödin (2017), Arbetsrätten- en översikt, $7^{\text {th }}$ ed., Wolters Kluwer, p. 109.

62 Svar till riksdagsfråga 2011/12:177 Billström Bärplockare och arbetskraftsinvandring; Svar på riksdagsfråga 2011/12:766 till Hillevi Engström.

63 Wingborg (2011), n. 53, p. 28. 
Kommunal had with the Federation of Swedish Forest and Agricultural Employers was chosen for berry pickers employed directly by Swedish companies, as some were at that time. For those employed by foreign temporary work agencies, the LO collective agreement for temporary work agencies would apply. ${ }^{64}$ Through this decision, a minimum wage level was set and the berry pickers were supposed to be guaranteed that level regardless of how many berries they picked. During the 2017 season, their guaranteed minimum wage was around 2100 euros per month before taxes. ${ }^{65}$

The Thai companies are asked to sign the collective agreement for temporary work agencies, and they normally do. However, this collective agreement is developed with other, more regular sectors in mind; it is difficult to make it effective in a sector with so few organised workers. For instance, the right to get access to the work site and check the working conditions normally depends on whether the trade union has any members on the site. Thus, an agreement adapted to the specific circumstances was needed. ${ }^{66}$ In 2014, a new, additional collective agreement was drafted to be concluded with foreign companies temporarily active in Sweden. Kommunal nowadays only gives opinions on an application for a work permit if the employer, the Thai temporary work agency, has signed this specific collective agreement. ${ }^{67}$

This additional agreement gives Kommunal the tools needed to monitor whether the conditions laid down in the main collective agreement are adhered to. It stipulates that the Codetermination Act should apply in full even if Kommunal has no members at the work site. According to the Codetermination Act, the trade union has a right to initiate consultations with the employer. The employer is also obliged to keep the trade union informed about developments in the company and any changes that take place. ${ }^{68}$ 'The trade union is given a right, through the collective agreement, to inspect working time and the occupational health and safety situation, through visits to the workplace, regardless of whether there are members working there or not. The employers are also obliged to hand over wage lists, picking lists, working time schedules, and other documents demanded by the local trade union. The local trade union, in this case Kommunals regionally based representatives, shall also be given signed employment

64 Woolfson et al., n. 8, p. 170.

65 The figures for 2017 come from an interview with a local Kommunal trade union representative on 7 June 2017 .

66 Wingborg (2011), n. 53, p. 7 .

67 The collective agreement (Kollektivavtal, Utländska företag, Häng, Fora).

68 Codetermination Act 1976:58o, secs. 10, 11, 12, 13, 19. 
evidence and employment contracts and monthly compilations of the number of workers and wages paid. ${ }^{69}$

Another important aspect clarified in the specific collective agreement is what wage deductions are permitted. According to the agreement, the employer is responsible for paying costs related to transport from accommodation to the work site, protective clothing, gloves, and hand-based tools that facilitate the picking. Costs for these things must never be deducted from wages. The employer may, however, deduct compensation for food and accommodation of normal standard at cost price..$^{70}$

Through these provisions, it is possible for Kommunal to detect inconsistencies with the collective agreement at an early stage and solve problems in Sweden. Hence, the new collective agreement stipulates that, if the parties to the collective agreement cannot solve a dispute themselves, then the dispute shall be referred to a Swedish court: all disputes regarding the interpretation and application of the collective agreement shall be solved by applying Swedish law. ${ }^{71}$ This provision is of great importance. It would obviously be much more difficult for the Swedish trade union to uphold the rights laid down in the collective agreement if disputes were to be solved by Thai courts.

\subsubsection{Membership Challenges}

A challenge many trade unions face in their work to promote fair working conditions for labour migrants is that the latter are often reluctant to become members of a trade union. In the statutes of most trade unions, one prerequisite for representing a worker or promoting their employment rights, is that they are a trade union member. This is also the case for Kommunal..$^{2}$ The reluctance to become a trade union member can be based on economic reasons - it is expensive to become a trade union member, and, on fears of reprisals and bad experiences from trade union activities back home..$^{73}$ Very few of the Thai berry pickers are members of Kommunal. To solve the problem of representation, Kommunal introduced a new, less expensive membership in 2016 for temporary labour migrants

69 Collective Agreement, n. 68.

70 Ibid.

71 Ibid.

72 Stadgar, Stadgar antagna vid Svenska kommunalarbetareförbundets kongress $2016, \S 2$ Förbundets ändamål, mom 2 Uppgift.

73 S. Eriksson (2016), Säsongsarbetaren från tredje land i dag och i framtiden, Examensarbete i civilrätt särskilt arbetsrätt, Juridiska institutionen Uppsala universitet, p. 33. 
with fixed-term employment. ${ }^{74}$ The idea was that the local trade union officials should campaign for this membership during the season of 2017.75 The Thai berry pickers, however, were not interested and none took advantage of this new membership. Thus, the membership challenge remains unresolved..$^{6}$

\section{Other Public and Private Stakeholders}

Other stakeholders have also played important roles in the effort to establish decent working and living conditions in this sector. The municipalities are responsible for ensuring that the accommodation provided fulfils the legal requirements regarding, for example, health and safety and fire protection. They have the authority to make inspections of the accommodations provided to the migrant workers to this end. When shortcomings are detected, the inspector can choose to issue a pure injunction, combine the injunction with a fine, or issue a ban. ${ }^{77}$ In 2016 , the municipalities detected a number of shortcomings regarding the berry pickers' accommodation..$^{8}$

Private stakeholders have also been active in promoting decent treatment of the migrant berry pickers. Many companies in the food retail industry have, for example, used a specific Social Audit.79 This code, like certifications, is an instrument of soft law, and enforcement is safeguarded through dialogue. One of the biggest retail companies conducts social inspections to verify that activities fulfil the requirements of the code. ${ }^{80}$ Another group of companies use the KRAV certification system, which mainly concerns ecological sustainability but also includes social requirements for the berry-picking sector. This certification is shown on products

74 Statutes adopted 2016. Stadgar antagna vid Svenska kommunalarbetarförbundets kongress 2016, § 4 mom 4 temporary membership.

75 Telephone interview with Jörgen Gustavsson Kommunal on 7 April 2017.

76 E-mail from Jörgen Gustavsson Kommunal, 10 March 2017.

77 See, for example, how the municipalities should organise their work in the report Miljösamverkan i Västerbotten, Slutrapport Tillfälliga externa boenden 2014-2015. Available at: http:// extra.lansstyrelsen.se/miljosamverkan/SiteCollectionDocuments/Publikationer/2015/2015tillfalliga-externa-boenden.pdf.

78 Wingborg (2016), n. 43, p. 14.

79 Ibid pp. 3-21.

80 Ibid. 
sold in Sweden. ${ }^{81}$ Formal enforcement of these instruments, however, is weak. $^{82}$

\section{Remaining Challenges}

The coordinated activities by the Migration Agency and Kommunal have been rather successful. The unscrupulous actors have been driven out of this regulated system but have found other arenas not covered by these rules; some of them deal with free berry pickers. ${ }^{83}$

Many of these free pickers are European nationals using their right to free movement as EU citizens when entering Sweden. ${ }^{84}$ They are described as 'free pickers' as they are not officially employed by anyone. They pick their berries as independent actors and sell them directly to the buyers. Currently, it seems that the worst problems with regard to extremely poor living conditions and low income are related to this group. As they are not 'workers' and many do not need a visa or work permit to enter Sweden, it is a challenge for the Swedish authorities and trade unions to improve their situation. This group's situation has been discussed elsewhere by others. ${ }^{85}$ The chapters by Schrauwen and Houwerzijl as well as by Cremers and Dekker in this volume also shed light on dilemmas surrounding free movement within the EU.

Some challenges, however, also remain in relation to the Thai berry pickers and the regulated system. The berry pickers normally take loans to pay for their tickets, visas, and other costs related to the journey to Sweden. Those costs correspond to approximately one month's minimum wage. On top of that, they have costs for accommodation and food while working in Sweden. The collective agreement stipulates that the berry pickers will earn the guaranteed wage level if they pick berries up to a certain value. If they pick berries above the minimum requirement, they will earn more

81 M. Wingborg (2015), n. 48, p. 10. More about KRAV available at: http://www.krav.se/english.

82 M. Wingborg (2013), 'Bärbranschen tar krafttag för bättre villkor I blåbärsskogen', Swedwatch rapport 6o, pp. 7-8.

83 See Section 3.2.

84 Consolidated version of the Treaty of the Functioning of the European Union (2012) OJ $\mathrm{C}_{326 / 56-57}$, Arts 20-21.

85 M. Wingborg (2016), n. 43, pp. 23 and 32. N. Mesic (2016), 'Paradoxes of European free movement in times of austerity: The role of social movement actors in framing the plight of Roma berry pickers in Sweden' International Journal of Sociology and Social Policy, 36(5/6) pp. 289-303; C. Woolfson and N. Mesic (2015), 'Roma pickers in Sweden: Economic crisis and new contingents of austerity' Transfer. European Review of Labour Research, 21(1) pp. 37-50. 
money. This means that their chances to earn more money depend on the market price of the berries. This price changes from year to year. In recent years, the price has gone down substantially, from two euros to one. The availability of picked berries on the international market has increased due to increased berry-picking activities in the Baltic states, Russia, and Ukraine. The low price has made it more difficult to recruit the Thai berry pickers. ${ }^{86}$ Another factor that affects the price is the level of antioxidants, which can change from year to year and from region to region, and is impossible to foresee. As already mentioned, most of the blueberries are sold to the pharmaceutical industry in Asia due to the high amounts of antioxidants. ${ }^{87}$ Thus, it is difficult to foresee the price six months ahead, which is normally when the berry pickers apply for the work permits. The allocation of risks involved in this unpredictability is unsatisfactory, and should be fairer in order to ensure that the pickers at least are debt-free when they get home. ${ }^{88}$

Another issue not yet discussed in this chapter is the fact that the berry pickers work very long hours. ${ }^{89}$ It is not unusual for a working day to last twelve to fifteen hours. Reports indicate that the berry pickers themselves do not feel exploited, as they would like to earn as much money as possible when they are in Sweden. From their perspective, the travel to Sweden is part of a sustainable household strategy..$^{90}$ Kommunal also seems to find it challenging to enforce that the working time provisions in the collective agreement are strictly upheld. ${ }^{91}$ It is unclear whether the sector would survive a strict application of the working time requirements. On the other hand, it is, of course, quite strange that this particular sector can operate freely outside the legal framework.

A somewhat different challenge is based on other grounds. The open Swedish labour migration system is not uncontroversial. In 2017, the Swedish Minister of Industry and the chairman of LO argued for a reinstatement of the labour market tests in Swedish labour migration law. ${ }^{92}$ Their argument is

\footnotetext{
86 M. Wingborg (2016), n. 43, pp. 15, 25.

87 Ibid p. 26.

88 Hedberg, n. 42, p. 145. M. Wingborg (2016), n. 43, p. 29.

89 Hedberg, n. 42, p. 133; The report on the 2016 season from the local trade union: Kommunal Mellersta Norrland, Skogsbärsverksamhet 2016 under perioden juni till oktober.

90 Hedberg, n. 42, pp. 133-134.

91 Kommunal Mellersta Norrland, n. 90.

92 DN DEBATT, Damberg \& Thorwaldsson, Vi vill ha nya regler for arbetskraftsinvandring. Available at: http://www.dn.se/debatt/vi-vill-ha-nya-regler-for-arbetskraftsinvandring/.
} 
that we must save easy jobs, like berry picking, for newly arrived refugees. ${ }^{93}$ It is still unclear how and whether the labour migration regime will change, but a proposed change in the tax regulations could, if adopted, make it less attractive for the Thai berry pickers to come to Sweden. ${ }^{94}$

\section{$6 \quad$ Conclusions}

It is clear that the story about the berry pickers in the Swedish forests confirms research that claims that the exploitation of labour migrants can be explained by the actual regulation of a specific labour market. Fudge and Tham have stressed 'the significance of labour regulation in shaping the quality and conditions of work' in a sector 'and in creating a sectorspecific demand for "low-skilled" migrant labour'.95 Before 2009, the sector was shaped by a combination of the lack of trade union interest in these workers and favourable tax provisions for employees of foreign temporary work agencies. When new labour migration provisions were adopted, new preconditions evolved, including both new challenges and opportunities. However, step by step, the preconditions for exploitation were removed. The Swedish trade union movement has taken on this sector and adjusted its working methods to its specific circumstances. This, in combination with increased targeted immigration control by the authorities, meaning, in this case, preventive inspection of the employers, has led to a positive result. The last major abuse involving Thai berry pickers was reported in 2013. ${ }^{96}$ The coordinated efforts have been successful, but still challenges remain and the system is not uncontroversial. The proposed tax regulation amendment will, and is maybe also intended to, make it less attractive for the Thai berry pickers to come to Sweden. In that case, the berry-picking industry will be left with domestic workers and free pickers. It is not obvious that the Swedish berry-picking industry will survive such a shift.

93 Ibid.

94 Swedish Tax Authorities, Skatteverket, beskattning och betalning av skatt vid tillfälligt arbete i Sverige, Dnr 202253985 17/13.

95 J. Fudge and J.-C. Tham (2018) 'Dishing Up Migrant Workers for the Canadian Food Services Sector: Labour Law and the Demand for Migrant Workers', Comparative Labour Law and Policy Journal, 39 (1) p. 1. See also M. Ruhs and B. Anderson (2008), 'Migrant Workers: Who Needs Them? A Framework for Analysis of Staff Shortages, Immigration and Public Policy' in Ruhs and Anderson (eds.), Who needs migrant workers?, Oxford University Press p. 46.

96 M. Wingborg (2016), n. 43, p. 28. 


\section{Bibliography}

Ahlberg, K. and Bruun, N. (2005), 'Sweden: Transition through Collective Bargaining' in T. Blanke, R. Blainpain, and E. Rose (eds.), Collective Bargaining and Wages in Comparative Perspective: Germany, France, the Netherlands, Sweden and the United Kingdom, Kluwer Law International, the Hague pp. 117-144.

Anderson, B. (2010), 'Migration, Immigration Controls and the Fashioning of Precarious Workers', Work, employment and society, 24(2) pp. 301-318.

Calleman, C. and Herzfeld Olsson, P. (2015), 'Inledning' in C. Calleman and P. Herzfeld Olsson (eds.), Arbetskraft från hela världen - hur blev det med 2008 års reform?, DELMI, Stockholm pp. 2-39.

Davies, A.C.L. (2014), 'Migrant Workers in Agriculture - A Legal Perspective' in C. Costello and M. Freedland (eds.), Migrants at Work, Oxford University Press, Oxford pp. 79-97 .

DN DEBATT, Damberg \& Thorwaldsson, Vi vill ha nya regler for arbetskraftsinvandring. Available at: http://www.dn.se/debatt/vi-vill-ha-nya-regler-forarbetskraftsinvandring/.

Eriksson, S. (2016), Säsongsarbetaren från tredje land i dag och i framtiden, Examensarbete i civilrätt särskilt arbetsrätt, Juridiska institutionen Uppsala universitet.

Fudge, J. (2012), 'Precarious Migrant Status and Precarious Employment - The Paradox of International Rights for Migrant Workers', Comparative Labour Law \& Policy Journal, 34 pp. 96-132.

Fudge, J. and Tham, J. (2018) 'Dishing Up Migrant Workers for the Canadian Food Services Sector: Labour Law and the Demand for Migrant Workers', Comparative Labour Law and Policy Journal 39(1) pp. 1-29.

Hedberg, C. (2015), 'Thailändska bärplockare - hushållsstrategier på en global arbetsmarknad', in C. Calleman and P. Herzfeld Olsson (eds.), Arbetskraft från hela världen, DELMI, Stockholm pp. 114-149.

Hunt, J. (2014), 'Making the CAP Fit: Responding to the Exploitation of Migrant Agricultural Workers in the EU', International Journal of Comparative Labour Law and Industrial Relations, 30(2) pp. 131-152.

ILO (2010), International Labour Migration. A rights-based approach, Geneva. Jonsson, L. and Uddstål, R. (2002), En beskrivning av den svenska skogsbärsbranschen, Sveriges Lantbruksuniversitet/Vindelns Försöksparker Umeå.

Krifors, K. (2017), Managing Migrant Workers - moral economies of temporary labour in the Swedish IT and wild berry industries, Linköping Studies in Arts and Sciences No. 717, Linköping.

LO (2013), Fusk och utnyttjande - om avregleringen av arbetskraftsinvandringen, Landsorganisationen i Sverige. 
Medlingsinstitutet (2017), Avtalsröreslen och lönebildningen 2016, Medlingsinstitutets årsrapport, Medlingsinstitutet, Stockholm.

Mesic, N. (2016), 'Paradoxes of European free movement in times of austerity: The role of social movement actors in framing the plight of Roma berry pickers in Sweden', International Journal of Sociology and Social Policy, 36(5/6) pp. 289-303. OECD (2011), Recruiting Immigrant Workers: Sweden 2011, OECD Paris.

Ruhs, M. and Anderson, B. (2008), 'Migrant Workers: Who Needs Them? A Framework for Analysis of Staff Shortages, Immigration and Public Policy' in M. Ruhs and B. Anderson (eds.), Who needs migrant workers?, Oxford University Press, Oxford pp. 15-52.

Sigeman, T. and Sjödin, E. (2017), Arbetsrätten - en översikt, $7^{\text {th }}$ ed., WoltersKluwer Stockholm,

Swedish Tax Authorities (2017), Skatteverket, beskattning och betalning av skattvid tillfälligt arbete i Sverige, Dnr 202253985 17/13.

Vogazides, L. and Hedberg C. (2014), Människohandel för tvångsarbete och exploatering av arbetskraft $i$ Sverige: Exempel från restaurang och bärbranscherna, ADSTRINGO, Council of the Baltic Sea States Task Force against Trafficking in Human Beings, Stockholm.

Wingborg, M. (2011), Mors lilla Olle - så exploateras asiatiska bärplockare i de svenska skogarna, Swedwatch rapport 41.

Wingborg, M. (2013), Bärbranschen tar krafttag för bättre villkor I blåbärsskogen Swedwatch rapport 60.

Wingborg, M. (2014), Villkoren för utländska bärplockare säsongen 2014, Arena Idé Stockholm.

Wingborg, M. (2015), Så var säsongen för utländska bärplockare 2015, Arena Idé Stockholm.

Wingborg, M. (2016), En alltmer osäker bransch - om villkoren för utländska bärplockare 2016, Arena Idé Stockholm.

Woolfson, C., Herzfeld Olsson, P. and Thörnqvist, C. (2012), 'Forced Labour and Migrant Berry Pickers in Sweden', The International Journal of Comparative Labour Law and Industrial Relations, 28(2) pp. 147-176.

Woolfson, C. and Mesic N. (2015), 'Roma pickers in Sweden: Economic crisis and new contingents of austerity', Transfer. European Review of Labour Research, 21(1) pp. 37-50.

\section{About the Author}

Petra Herzfeld Olsson is associate professor in private law and senior lecturer in labour law, Stockholm University, Sweden. 
